\title{
Tessenei (1905-1941): intensive farming shaping landscape and social relations in colonial Eritrea
}

\author{
Nelly Cattaneo ${ }^{1,1}$ \\ ${ }^{1}$ Politecnico di Milano, Department of Architecture and Urban Studies, 20133 Milan, Italy
}

\begin{abstract}
In the early 20th century the agrarian policies of the Colonial Government in Eritrea moved from the promotion of Italian family homesteads on the highlands to the exploitation of wide semi-arid areas in the lowlands. In particular the surroundings of Tessenei, close to the Sudanese border, for its geomorphological and hydrographic features, were appropriate for a wide intensive plantation of cotton. Here in 1905 the most meaningful intervention of colonial agrarian valorisation in Eritrea was being planned, but it was realized at the end of the Twenties. Barriers, embankments, canals and drains caused then a radical change in the landscape, imposing a severe geometry over 10.000 hectares of smoothly corrugated lands around the Gash River. Production activities were mainly based on local workers: this had a dramatic impact on traditional culture and social relations, stressed by the fact that in a short while migration from Sudan and Ethiopia was encouraged. By analysing the main features of the spatial organization designed in Tessenei, an attempt to outline the relation between the colonial government and local cultural system will be made; the comprehension of this relation would be important to understand the legacies of the project and its potentialities at present.
\end{abstract}

\section{Tessenei in the history of colonial Eritrea}

In the second half of the $19^{\text {th }}$ century, in the scramble for Africa engaged in by most European countries, the new born kingdom of Italy had slowly occupied land in the Horn and in 1890 named it Colonia Eritrea. It was not a rich land in terms of resources, but Italy was dealing with an impressive migratory flow and the green and fertile Eritrean highlands had been considered an opportunity to create the conditions for a demographic colony [1, 2, 3]. The first colonial agricultural policy (1891-1896) was based on a wholesale governmental acquisition of the areas farmed by local inhabitants, to be later assigned to Italian families ${ }^{2}$; as no comprehensive plans to

\footnotetext{
${ }^{1}$ Corresponding author: nelly.cattaneo@polimi.it

${ }^{2}$ Many essays have dealt with the topic of Land Tenure, and the impact of colonial policies on traditional laws; among the many three can be pointed out for the different points of view they represent: in [4] an overview on traditional law systems and colonial legislation is provided; in [5] although very technical, the aim is at underlining the efforts made by the government to support
} 
support the creation of homesteads were pursued, and the local population reacted to the misappropriation of their lands, this policy soon proved to be a failure $[4,5,6]$. After the ruinous Italian defeat at Adua (1896), the first civilian Governor, Ferdinando Martini ${ }^{3}$, changed strategy in agricultural policies and paid attention to the lowlands. These wide flat areas, fertile as well, populated by semi-nomadic shepherds and therefore only partially farmed, for climatic reasons were not appropriate for family homesteads, but could comply with a different type of colonization, aimed at companies interested in industrial farming, in particular growing cotton. In the western lowlands, satisfactory attempts to grow cotton were financed by companies from Northern Italy, where the textile industry was well developed [7:57-58]. These efforts were justified by the driving need to counteract the monopoly in cotton production held by the United States of America and England [8].

In the lowlands of Eritrea, thanks to climatic and hydrographic conditions, cotton farming could give good results. In these areas seasonal rivers run for several weeks a year from the highlands eastwards to the Red Sea, or westwards to the lowlands, but there was a lack of permanent water, necessary for agricultural purposes. According to studies of the time $[9,10]$, it was nonetheless possible to take advantage of seasonal watercourses by creating barriers and dams to retain an adequate amount of water for annual irrigation.

In 1905 hydraulic Engineer Nicola Coletta was appointed by the Ministry of Italian Colonies to make a technical survey along the Gash River, which, starting from the Hamasien plateau, eventually scatters its water to the West, beyond the Sudanese border. Gash River was the watercourse that, for location and flow rate, could offer the best conditions in creating a wide irrigated system; Eng. Nicola Coletta identified in the surroundings of an area called Tessenei the optimum place to build a barrage [11].

A watering place for herds, which Italians had never even mentioned on their maps, was fitting to be transformed into the most ambitious governmental agricultural intervention in Eritrea. In 1906 Engineers Nobile and Avetrani were recruited to make a detailed study of the hydraulic rate of Gash River, and of the topography of the area. The executive project was delivered in 1909; nevertheless for a lack of favourable general conditions, the project was not carried out ${ }^{4}$. In 1923 Jacopo Gasparini ${ }^{5}$, who was the first Governor of Eritrea of the fascist period, resumed the project without modifications as a part of a wider plan for the Colony, which aimed at making high profits from trade, based on the strategic position of Massawa harbour [2, 3].

Gasparini's reconsideration of the project perfectly fitted the rise of fascist rhetoric: Tessenei had to become the Eritrean site able to promote the new fascist man, who could fulfil super-human endeavours [12]. At the same time it was a demonstration of self-reliance towards Anglo-Egyptian neighbours ${ }^{6}$, who had until then benefitted totally from the water of Gash River. Moreover, the results achieved by the Villaggio Duca

Italian settlers in the respect of local inhabitants (which was actually a necessity); in [6] the main topic concerns the effects of the imposition of colonial land tenure.

${ }^{3}$ Ferdinando Martini was Governor of Eritrea from 1897 until 1907.

${ }^{4}$ On one side, the project had to go along with other interventions of general valorisation, such as transport facilities at a large scale, which could not be fulfilled for economic reasons. On the other side the increasing Italian interest for the North of Africa and the beginning of the First World War relegated Eritrea into an even more marginal position in colonial policies.

${ }^{5}$ Governor of Eritrea from 1923 until 1928.

${ }^{6}$ The Anglo-Italian agreement for the use of Gash River water is based on the decree of 28 April 1927 n.1192, signed by Gasparini and by Wasey Sterry, on negotiations started in 1924. 
degli Abruzzi $^{7}$ in Italian Somalia, which had characteristics similar to the project for Tessenei, were probably a trigger for the Eritrean Governor to undertake in 1924 such a demanding project in the so called "firstborn colony".

Except for publications, articles and newsreel of the time, severely affected by the need to exalt Italian planning capabilities and achievements, and some studies by Irma Taddia during the 1980 s $[12,13,14,15,16,17,18]$, not much documentary evidence is available regarding Tessenei and its impact on local cultures. The aim of this work is therefore to provide the basic information collected through bibliographical and archival research, and to suggest a first analysis of the side effects of the realization of Tessenei on local cultures.

\section{From hydraulic engineering principles to a new landscape}

Before recalling the planning steps followed by Coletta, Nobile and Avetrana, it is important to underline that, among the rural works undertaken in the Colony, Tessenei marked the passage from an empirical approach to a planning process that combined the technical and scientific knowledge achieved in the motherland, and applied it to the new context. Calculations turned agronomic requirements, topographic observations and hydraulic parameters into geometries and measures, shaping the land through a logical and mathematical process ${ }^{8}$.

The starting point for the entire project was the need to produce tropical crops in high demand in Italy, in particular cotton. Previous scattered experiences with cotton farming in Eritrea ${ }^{9}$, and observations conducted by agronomists like Bartolommei-Gioli and Isaia Baldrati ${ }^{10}$, showed that some areas provided optimal conditions for this kind of farming $[9,10]$. To maximize both yield and profit, a specific variety of cotton was selected, called Sakellaridis, which combined good quality and climatic suitability, and had a specific requirement for water [10]. Due to the seasonality of watercourses, the most appropriate farming technique to be adopted was spate irrigation. On these bases Eng. Coletta could set the data of the problem, combining direct observations on site with the available rainfall and hydrometric information.

The Gash watershed upstream of Tessenei is over 22,000 square kilometres in area. Although it has a seasonal summer course, it was estimated to reach a hydraulic flow of 300 cubic metres per second that made a project based on the construction of a barrage profitable. The optimal place was found in Tessenei because there the river-

\footnotetext{
7 In 1919, the Italian prince Luigi Amedeo di Savoia, Duca degli Abruzzi, stepped away from the political roman circle and started the exploration of parts of the Italian Somalia searching for lands to reclaim. At $120 \mathrm{~km}$ from Mogadisho, on the Uebi Scebeli river, he acquired 25.000 hectares of land, and in 1920 founded the Società Agricola Italo-Somala (SAIS) and started building barriers and channels to enable cotton farming. The Villaggio Duca degli Abruzzi was strongly characterised by the narrative of the "prince-farmer", which was lately amplified and exploited by the fascist rhetoric. See [2: 869-872], also about the unfair working conditions for local people.

8 Smaller attempts of similar interventions, but not based on an analytical project, were fulfilled in the first decades of the $20^{\text {th }}$ century in Emberemi, Uachiro and Zula, along the coast, but also in Carcabat, in the western lowlands.

9 Good results in cotton farming in Eritrea had been achieved by Padre Giovanni Stella in the agricultural colony of Sciotel, near Keren (1867-1869), and by companies farming in Carcabat.

${ }^{10}$ Gino Bartolommei Gioli was a professor of Agriculture engaged in 1901 to study problems and potentialities for agrarian exploitation of Eritrea. Isaia Baldrati was director of the Agrarian Office of Eritrea for several decades since 1909.
} 
bed is made of solid granite, so no expensive foundation work would have been necessary. In addition, on the left side of the river, the elevation of the land decreases towards the west and that made it possible to divert water by means of simple canals, without using pumping systems and mechanical devices.

Agronomic studies recommended that to grow the Sakellaridis variety of cotton on the type of soil found in Tessenei using the spate irrigation technique, a depth of 60 centimetres of water had to be delivered to the fields before seeding. During the 50 days of seasonal water and with a minimum guarantee flow of 10 cubic metres per second (which would be 14 in the final project), it was possible to water, with an acceptable margin of error, 15,000 hectares, which could be expanded later on, after gaining experience. The Gash River would have supplied half of the amount of water, direct rain and flushing water would have provided the other half [12].

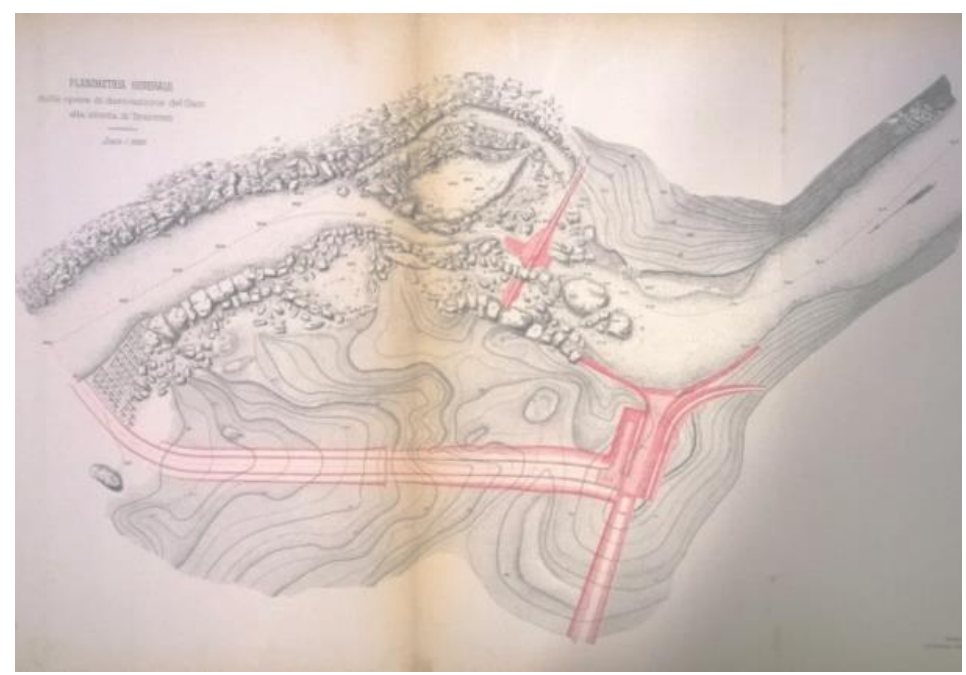

Fig. 1. The plan of the barrage, the moderator and the overflow channels. Source: [11].

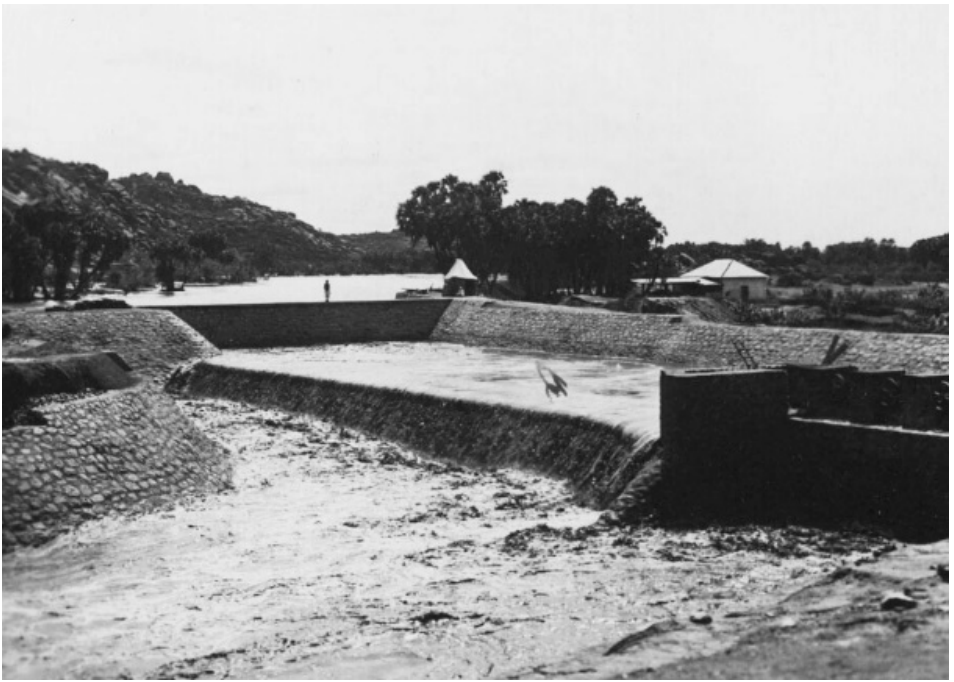

Fig. 2. The main dam and the overflow channel.

Source: Biblioteca Nazionale Centrale di Roma, Archivio fotografico IsIAO, E-1-CIII-XIV). 
In 1906 Nobile and Avetrana were engaged to study in detail the technical solutions and to deliver the executive project: they designed the main dam meant to facilitate the entrance of water into the moderator channel; hence an overflow channel redirected excess water into the Gash River, and just beside it, the outlet-building controlled the seepage of water into the primary channel.

The path of the primary channel was of paramount importance for the functioning of the whole system downstream, and it determined the geometric layout of the entire area. The slope had to guarantee an average speed of 0,55 metres per second, in order to reduce the erosion of the banks and to maintain the suspension of the silt, which had to be deposited inside the fields. The slope was therefore extremely gentle and the resulting path of the canal proved to be winding, as it was not moving away much from the correspondent natural contour line. Every two kilometres secondary channels branched off the primary one: their path followed straight lines of maximum gradient, and water speed was controlled by a sequence of steps. The third level of channels, leading the water directly into the fields or into minor channels, followed again the winding of the contour lines [11, 12]. According to spate irrigation technique, the perimeters of the fields was marked by soil embankments, to retain water until its complete absorption by the soil of the fields.

The landscape generated constituted a dramatic change: the heavy deforestation carried out and the reclamation works created a wide and flat empty space - therefore lacking of spontaneous natural resources - based on a geometric pattern made of planes and canals, contrasting with the green and corrugated surroundings. The water in Tessenei, from scarce resource or violent river-flow, could now be stored, but not under the will and the control of local people.

It is a logical follow on, that these changes had impacts which shifted from landscape and production to local culture: farming was no longer based on traditional knowledge and understanding of the environment, but it turned to be a set of fractionated activities that had to be planned and managed by a centralized external authority [18]. The landscape was the physical layout of this new organization.

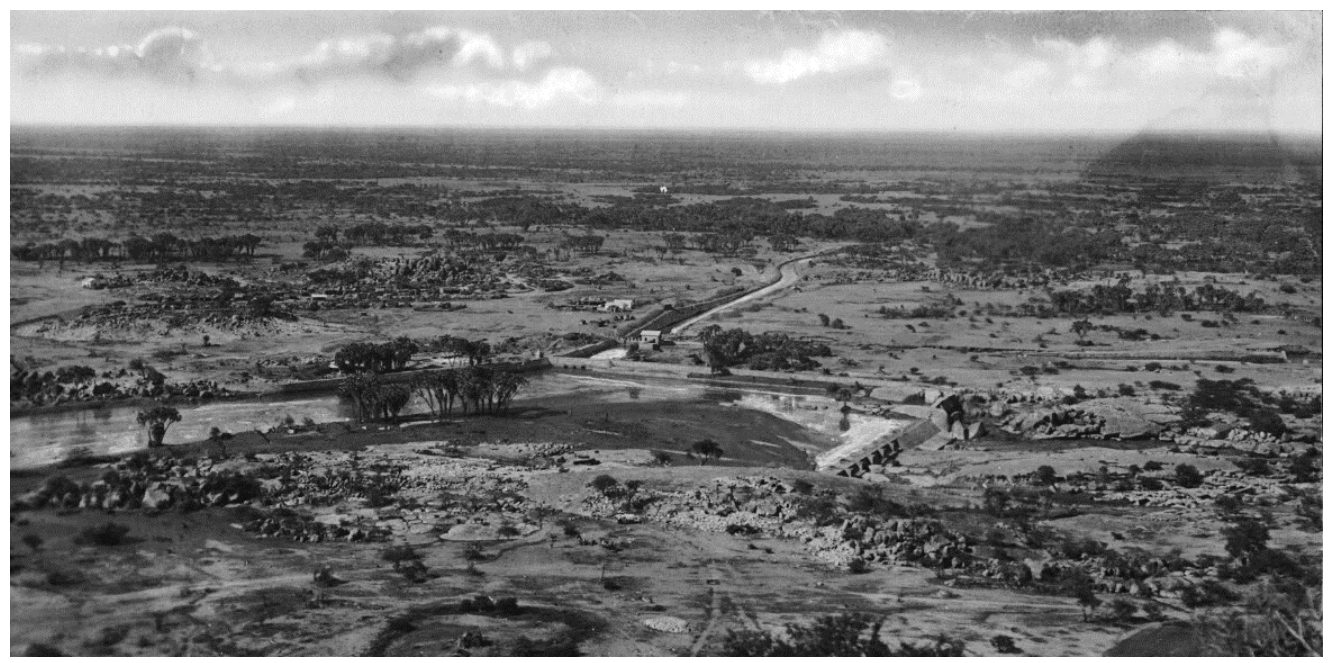

Fig. 3. The area of Tessenei. Source: Biblioteca Nazionale Centrale di Roma, Archivio fotografico IsIAO, E1-CIII-XIV 3. 


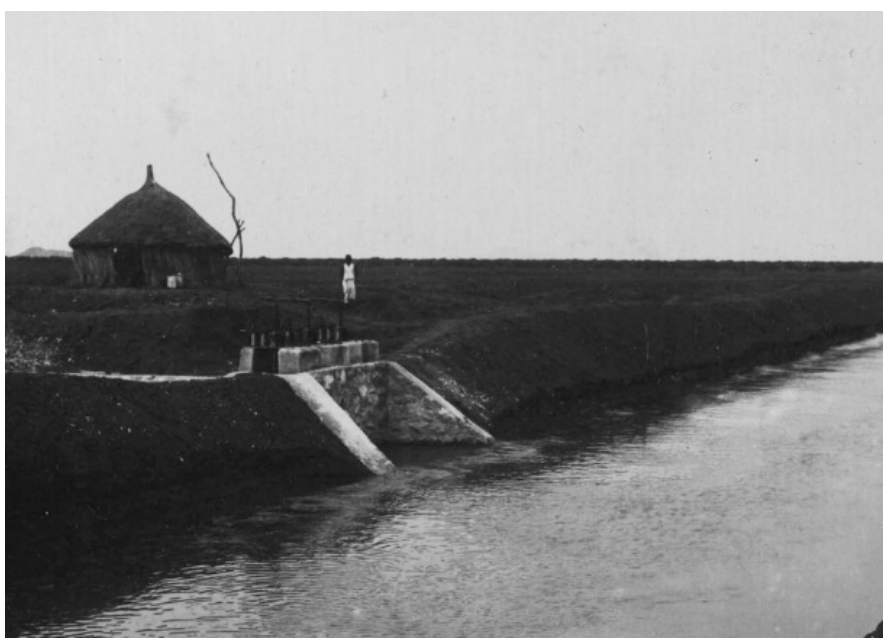

Fig. 4. The primary channel.

Source: Biblioteca Nazionale Centrale di Roma, Archivio fotografico IsIAO, E-IIC-2IV-9.

\section{Changes in cultural landscape}

As climatic conditions in the lowlands were uncomfortable for Europeans, workers had to be found among local populations, which were not numerous and, in that region, were not necessarily sedentary. According to the information provided by the Touring Club Italiano (TCl), by 1929 around one thousand families had settled in Tessenei [19]. They belonged mainly to Cunama and Beni Amer peoples, who had already been engaged for the dam works. The fields were assigned to farmers and families through a sharecropping contract. The amount of land assigned was from 2 to 5 feddan $^{11}$, depending on the working potential of the family.

The contract between the Government and the farmers is still very interesting for the mixture of references to traditional laws and colonial obligations [13]. The meaningful articles dealing with the organization of the production can be summarized as follows:

- on eight parts of the land assigned to each family, it was mandatory to grow cotton, on two parts, the less watered, dura ${ }^{12}$ for family use;

- cotton had to be divided in two between the government and the farmer, but it had to be entirely carried to the government sheller by the farmer, who was paid his half. All the dura was left to the farmer.

Some croppers were engaged only in dura farming: in this case the farmer was provided the seeds by the Government and had to give back one quintal of dura per feddan.

Delivering the harvested cotton to a centralized place for its transformation was a break in the traditional transformation process of resources and production of goods; and this also caused side effects in family roles and activities. Being provided with seeds every year caused a limitation of local people self-reliance and a depletion in cultural variety in the long term. But for the government the benefits seemed to be meaningful: chronic food deficit was reduced by dura farming, and people even from distant areas with a shortage of land to farm had a place to move to.

11 Local unit of measure, used in contracts and usually rounded off at 4000 square metres.

12 Dura, local name for Sorghum, was the base of daily feeding. 
Difficulties and costs in transport made it profitable to transform the product on site from the beginning, and in fact in 1926 a sheller was built and equipped with the whole set of machinery needed to shell the cotton and to press the fibres. In 1931 SIA (Società Imprese Africane), founded and run by the former Governor Gasparini, took over the entire area and the production line, adding an oil mill and a soap factory.

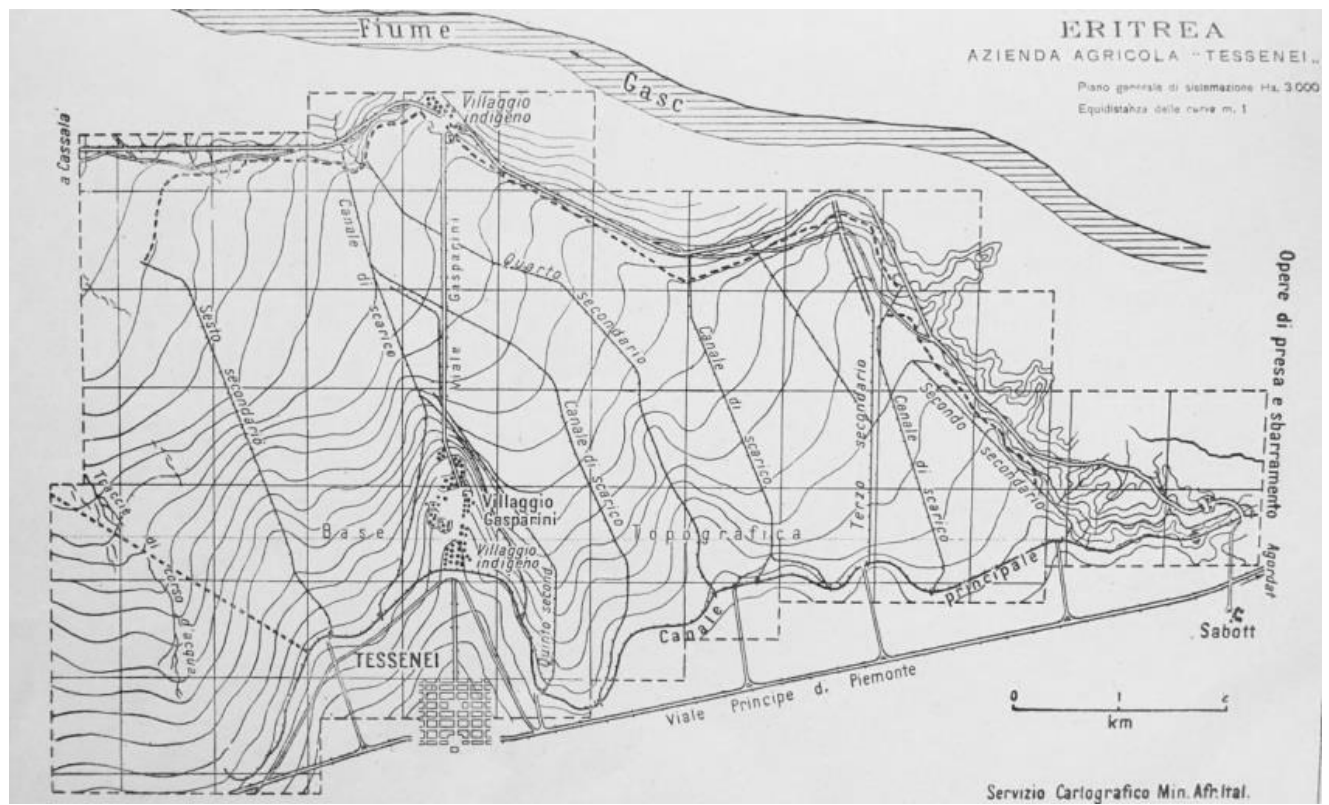

Fig. 5. The map of Tessenei farming area. Source: Istituto Agricolo Coloniale, 1947.

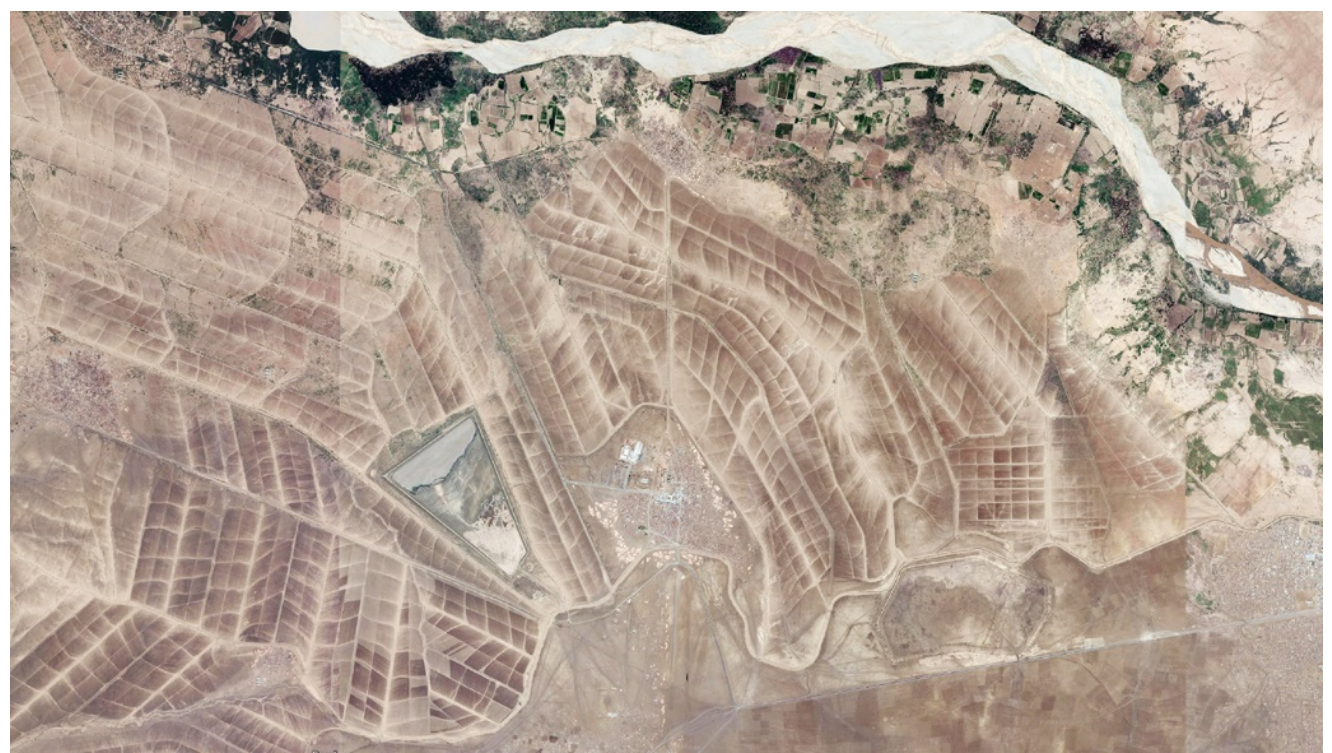

Fig.6. The map of Tessenei farming area. Source: @ DigitalGlobe 2018 @ Google 2018.

According to the information reported by $\mathrm{TCl}$, in 1938 Tessenei fields were in let out to 320 families of farmers [20]. Tessenei, which might be intended as a name referring to the aggregation of several villages, had 1850 inhabitants of whom only 50 were 
Italian; nonetheless it was possible to find the Residenza - the representative building of the Colonial Government -, the post office, a little hospital, S.I.A. offices, and even the Casa del Fascio - the representative building of the Fascist power. The geometrical core of the farmed area, named Villaggio Gasparini, was planned along a North-South axis. Just south of Villaggio Gasparini, a new town, never built, was designed on a regular grid as often used in colonial planning just to mark the difference between the organic settlements of local population and the rational geometry of the ruler.

Tessenei became attractive for several reasons. The area had a very low population and, among the variety of ethnic groups of the region, Beni Amer and Cunama were the two main ones. The first were semi-nomadic, living on pastoralism, the second had a valuable agricultural tradition due to a very peculiar cultural position among other ethnic groups: they were regular victims of raids and led into slavery by other populations, so their main settlements were in remote and inaccessible areas where they lived on terraced farming [21]. Their agricultural skills were highly appreciated by the colonial authorities. Maria, Bilen, Atmariam, At Tacles, Baria, Amara were other ethnic groups providing manpower.

According to articles of the time, manpower was attracted by Tessenei from a wider area: many workers from Yemen had been hired for the preparation works because of their ability in making soil embankments and ducts, as spate irrigation was a traditional farming technique since antiquity on the other side of the Red $\mathrm{Sea}^{13}$. Sudanese and Ethiopians arrived from inner areas of the bordering countries. Moreover, Tekrur, a name generally used to call pilgrims coming from western Africa and directed to Mecca, often stopped for several months or years with their families in Tessenei, on their way to Massawa harbour, because they could earn enough to continue their pilgrimage $[7,22]$.

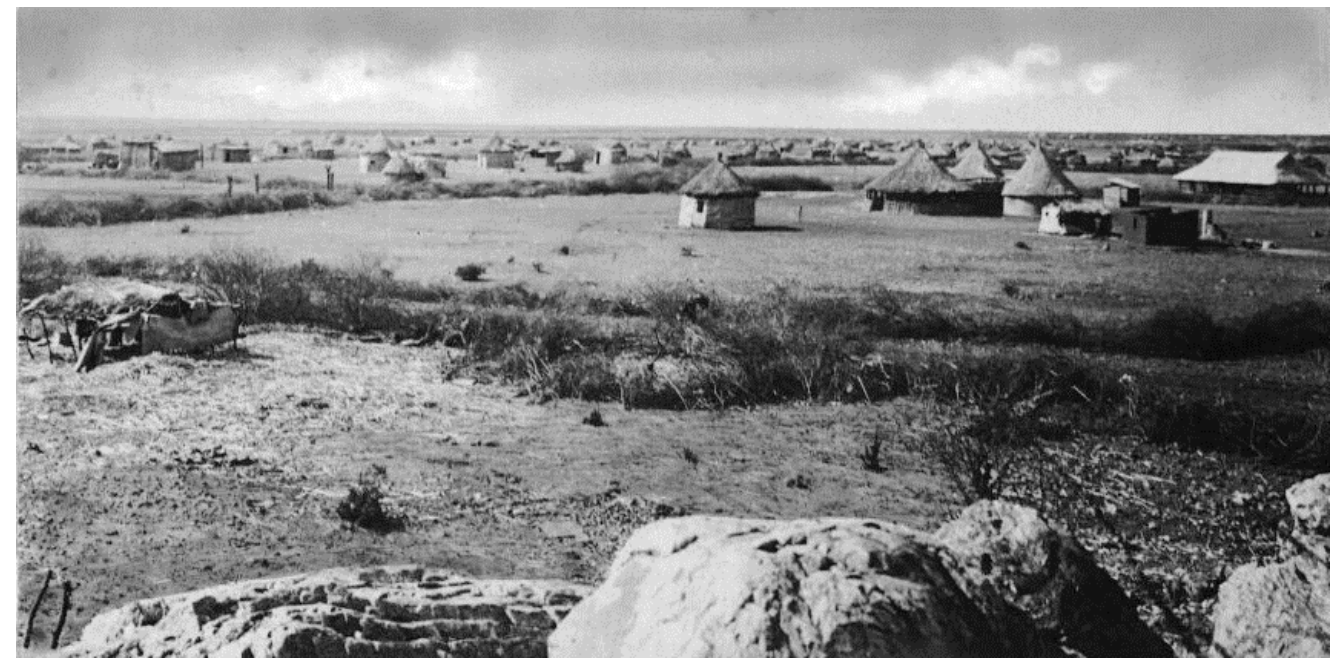

Fig. 7. The area of Tessenei.

Source: Biblioteca Nazionale Centrale di Roma, Archivio fotografico IsIAO, E1-CIII-XIV 35.

${ }^{13}$ Migration from Yemen to Eritrean Colony is already mentioned in the annual reports by Governor Martini at the end of the $19^{\text {th }}$ century, when Yemeni families had been engaged to start coffee farming in the Colony. In 1920s Governor Gasparini developed a diplomatic and commercial policy oriented to strengthen the relations with Yemen. 
The farmers were grouped in new settlements according to ethnicity. Each group had a chief, who was in charge of keeping order in compliance with traditional laws. Families lived in straw huts, inappropriately called tukuls ${ }^{14}$, provided by the government. They were settled in little villages: the main three were Sabott, Alighidir and Villaggio Pozzo n. 10, i.e. Village Well n. 10, plus eight more groups of huts. Some shacks were built for housing little shops. The dwellings for the farmers, as it is possible to infer from the very few photographs available from that time, seem to follow traditional spatial rules, suggesting that organization of daily life was definitely not a commitment of the Italian ruler ${ }^{15}$.

This concentrated population, relatively wealthy thanks to the income coming from the surplus, turned this area into a new important market, which became the main destination for some of the traders previously directed to Cassala, in Sudan; in less than ten years, from being peripheral, this area became a new regional centre. A truck road was built in the late twenties to connect Tessenei to Agordat, which was the last town reached by the colonial road system, and the government planned to extend the railway line Massawa-Asmara-Cheren-Agordat to Tessenei, but the works stopped in Biscia in 1935 because of other priorities due to the war with Ethiopia.

In the early 1930 s Armando Maugini ${ }^{16}$ had already made acute general observations about the perturbations caused by colonial agricultural interventions on the sociocultural system. He remarked that indigenous farming used to have a family nature, and that family represented in many cases a real and varied economic venture. The mirage of a salary and the rising of living costs estranged most indigenous people from traditional occupation and from family ties.

Maugini also recognized that the traditional productive organization, apparently poor, being based on diversification of activities and in some cases with no territorial fixity, was by contrast an admirable phenomenon of adaptation to the environment, i.e. what we would now call resiliency. At the same time Italian farms, being more perfected and expensive, were also more fragile, while the indigenous farmer protected himself thanks to his limited needs and his extreme mobility. That is why in the 1930s, after destructive floods and locusts invasions, and after the collapse of cotton price as a result of the $1929 \mathrm{crash}$, SIA had to exploit spontaneous vegetation around Tessenei in order to improve the low incomes of the company; SIA was licensed to collect natural rubber, dum palm seeds, wild honey, etc. all over the western lowlands ${ }^{17}$. These activities could be fulfilled by taking advantage on the traditional knowledge of the people settled in Tessenei; just to mention one example, Tekrur and Sudanese also brought in the skills of collecting natural rubber [23].

\footnotetext{
${ }^{14}$ It is important to remark one of the most frequent simplification made by the Colonial Government: tukul is used to name any circular structure with conical roof, although the dwelling in use in Tessenei is more similar to the ità of Cunama people.

${ }^{15}$ Also Ascari, i.e., the indigenous corps under the Italian army were usually housed in tukuls, but all aligned in rows as in any military camp.

${ }^{16}$ Maugini had been Director of the Istituto Agricolo Coloniale Italiano (Italian Colonial Agricultural Institute) since 1924.

17 Beside rubber, also palma dum seeds -also called vegetal ivory and used in button manufacturing - andropogon and wild honey were included in the economic activities, in order to counterbalance the slump in the price of cotton due to the 1929 crisis.
} 


\section{Conclusions and future research}

The project in Tessenei could only be analysed through Italian references of that time, which is a strong limitation for understanding its real impact on local cultures in the short and long term. Nevertheless, the aim of this work was to retrace the main elements of its design and early history, and to point out the main issues involved in this part of Italian colonial past. Some of these issues identify the entanglement of colonial relations, which shift from landscape to various aspects of culture and, above all, are clearly not unidirectional. Tessenei in fact took advantage not only of regional labour, but also of local and regional knowledge. This would therefore be a fruitful case study to investigate the complexity and multiculturalism of Eritrean Colonial Shared Heritage.

\section{Short resume}

Nelly Cattaneo graduated in Architecture at Politecnico di Milano in 2003. In 2004 she started collaborating with DIIAR (Hydraulic Engineering and Surveying Department) of Politecnico di Milano in the development of topographic databases. In 2007 she started a Research Fellowship at BEST (Building Environment Science \& Technology) which led her to conduct surveys on historical sites. Trying to combine her experience in geographical data analyses and in Cultural Heritage Preservation, since 2015 she is PhD candidate in Preservation of Architectural Heritage, in the field of Historical Landscape, focusing on colonial and post-colonial landscape in Eritrea.

\section{References}

1. MIEGE, J.L. (1968) 1976. L'imperialismo coloniale italiano dal 1870 ai giorni nostri, Milan, Rizzoli Editore.

2. DEL BOCA, A. (1976) 2001. Gli italiani in Africa Orientale - I. Dall'unità alla marcia su Roma, Milan, Mondadori.

3. DEL BOCA, A. (1979) 2001. Gli italiani in Africa Orientale - II. La conquista dell'Impero, Milan, Mondadori.

4. MANCUSO, S. 2010. Terra in Africa. Diritto fondiario eritreo, Trieste, Edizioni Università di Trieste.

5. SERTOLI SALIS, L. 1932. L'ordinamento fondiario eritreo, Padova, CEDAM.

6. TEKESTE, N. 1986. No Medicine for the Bite of a White Snake: Notes on Nationalism and Resistance in Eritrea, 1890-1940, Uppsala, Reprocentralen.

7. BOLOGNA, L.M.; CONFORTI, E.; CHIUDERI, A. et al. 1970. L'Italia in Africa L'avvaloramento e la colonizzazione. Tomo II: L'opera di avvaloramento agricolo e zootecnico in Eritrea, in Somalia e in Etiopia. Rome, Soc. Abete.

8. COLOSIMO, G. 1918. Relazione al Parlamento sulla situazione politica, economica ed amministrativa delle colonie italiane: presentata alla Camera dei Deputati il 23 febbraio 1918 ed al Senato del Regno il 28 febbraio 1918, Rome, Tipografia del Senato.

9. BARTOLOMMEI GIOLI, G. 1903. La colonizzazione agricola dell'Eritrea, Florence, B. Seeber.

10. BALDRATI, I. 1913. “L'agricoltura nell'Eritrea”, in s.n. L'Eritrea economica, RomeNovara, Istituto Geografico De Agostini: 283-328. 
11. NOBILE, G.B. 1913. Progetto di irrigazione della pianura di Tessenei con le acque del fiume Gasc nella colonia Eritrea, Rome, Tipografia della Camera.

12. "Una grande opera compiuta" (1927). Bollettino commerciale della Colonia Eritrea, vol. 6, n 66: 213-220.

13. "Notiziario economico dai Commissariati" (1928). Bollettino economico dell'Eritrea, vol. 1, n' 1: 9.

14. "La valorizzazione agricola dell'Eritrea" (1925). Bollettino commerciale della Colonia Eritrea, vol. 4, $\mathrm{n}^{\circ}$ 36: 212-213.

15. "Notiziario economico dai Commissariati" (1926). Bollettino commerciale della Colonia Eritrea, vol. 5, $\mathrm{n}^{\circ}$ 43: 337.

16. "Lavori di Tessenei" (1926). Bollettino commerciale della Colonia Eritrea, vol. 5, $\mathrm{n}^{\circ}$ 51: 511.

17. DE ROSSI, G. 1931. "Le bonifiche nella Colonia Eritrea", L'Oltremare, vol. 5, $n^{\circ} 4$.

18. TADDIA, I. 1986. L'Eritrea-colonia 1890-1952 - Personaggi, strutture, uomini del colonialismo, Milan, Franco Angeli.

19. BERTARELLI, L.V. 1929. Guida d'Italia: possedimenti e colonie: isole Egee, Tripolitania, Cirenaica, Eritrea, Somalia, Milan, Touring Club Italiano.

20. C.T.I., 1938. Guida dell'Africa Orientale Italiana, Milan, Consociazione Turistica Italiana.

21. MAUGINI, A. 1931. Le Colonie Italiane di diretto dominio, Rome, Ministero delle Colonie.

22. ELLERO, G. 1947. "I Tacruri in Eritrea", Rassegna di Studi Etiopici, vol. 6, $\mathrm{n}^{\circ}$ 2: $189-199$.

23. ISTITUTO AGRICOLO COLONIALE, 1947. L'agricoltura nella Colonie Eritrea e l'opera dell'talia, Rome, Tipografia del Senato.

24. L'economia eritrea (1932). Florence, Istituto Agricolo coloniale italiano.

25. Lavori di Bonifica nella terra dei Tessenei. II raccolto (1940). Newsreel [Online video]. GEMMITI, A. (art.dir.). Italy: Istituto Nazionale Luce. [Source: Archivio Storico Luce, Giornale Luce C / C0071]. Retrieved from:

https://www.youtube.com/watch?v=MBBIDnTtyhc [available on 5 April 2018] 